\title{
Diet of grey-headed albatrosses at the Diego Ramírez Islands, Chile: ecological implications
}

\author{
JAVIER ARATA $^{1 *}$, GRAHAM ROBERTSON², JOSÉ VALENCIA ${ }^{3}$, JOSÉ C. XAVIER ${ }^{4}$ and CARLOS A. MORENO ${ }^{1}$ \\ ${ }^{1}$ Instituto de Ecología y Evolución, Campus Isla Teja, Casilla 567, Universidad Austral de Chile, Valdivia, Chile \\ ${ }^{2}$ Australian Antarctic Division, Channel Highway, Kingston, TAS 7050, Australia \\ ${ }^{3}$ Instituto Antártico Chileno, Plaza Muñoz Gamero 1055, Punta Arenas, Chile \\ ${ }^{4}$ British Antarctic Survey, NERC, High Cross, Madingley Road, Cambridge CB3 OET, UK \\ *Corresponding author: javierarata@entelchile.net
}

\begin{abstract}
The diet of grey-headed albatrosses at Diego Ramírez was analysed and compared to that of the sympatric black-browed albatross. Diet composition was inferred from an analysis of prey hard parts present in 103 chick regurgitates obtained during breeding seasons 2000, 2001 and 2002. The squid Martialia hyadesi predominated in the diet samples in 2001 and 2002 (89\% and $81 \%$ of reconstituted mass), but was absent from the 2000 samples. Reconstituted mean mass per sample in 2000 was significantly lower than in 2001 and 2002. Chick growth rate during 2000 was also the lowest recorded. This suggests that $M$. hyadesi plays an important role in the breeding performance of grey-headed albatrosses at Diego Ramírez. Low presence of M. hyadesi in grey-headed albatrosses' diet at South Georgia in 2000, a year with significant low breeding success, suggests ocean-wide processes affecting the availability of this prey to both populations simultaneously. Overlap in diet composition, and inferred feeding areas, between the sympatric albatross species at Diego Ramírez was minimal. Grey-headed albatrosses fed mainly on species associated with the Antarctic Polar Front, whereas black-browed albatrosses consumed benthopelagic species frequently caught in fishing operations in southern Chile.
\end{abstract}

\section{Received 10 July 2003, accepted 20 April 2004}

Key words: ENSO, niche partitioning, squid, sympatry, Thalassarche chrysostoma, T. melanophrys

\section{Introduction}

Grey-headed albatrosses (Thalassarche chrysostoma [Foster, 1785]) forage over vast areas of ocean even during breeding seasons, when time away from colonies and distance travelled are constrained by the need to feed their young regularly. For example, at Campbell Island $\left(52^{\circ} 33^{\prime} \mathrm{S}\right.$, $\left.169^{\circ} 09^{\prime} \mathrm{E}\right)$ and Marion Island $\left(46^{\circ} 54^{\prime} \mathrm{S}, 37^{\circ} 45^{\prime} \mathrm{E}\right)$, greyheaded albatrosses foraged more than $1000 \mathrm{~km}$ from their colonies during breeding (Waugh et al. 1999, Nel et al. 2000). This capacity for long oceanic flight allows this albatross species to have access to a range of marine habitats, including oceanic frontal zones (such as the Antarctic Polar Frontal Zone) and waters associated with seamounts, continental shelves and slopes surrounding them. In all colonies studied, grey-headed albatrosses exploit both 'natural' food sources and food made available by commercial fisheries (e.g. Rodhouse et al. 1996, Waugh et al. 1999, Nel et al. 2000, Cherel et al. 2002).

The Diego Ramírez Islands $\left(56^{\circ} 31^{\prime} \mathrm{S}, 68^{\circ} 44^{\prime} \mathrm{W}\right)$ are one of eight known breeding sites for grey-headed albatrosses in the world and constitutes the second largest breeding population of the species (Gales 1998). It is the southernmost breeding site for the species, situated in the Drake Passage, 60 nautical miles (n.m.) south-west of the Cape Horn (Chile) and 430 n.m. north-west from the Antarctic Peninsula, in close proximity to the Antarctic
Polar Front (Fig. 1). The particular location of the Diego Ramírez Islands offers grey-headed albatrosses the potential to exploit cephalopods and fish in sub-Antarctic and Antarctic waters (Waugh et al. 1999, Nel et al. 2001, Cherel

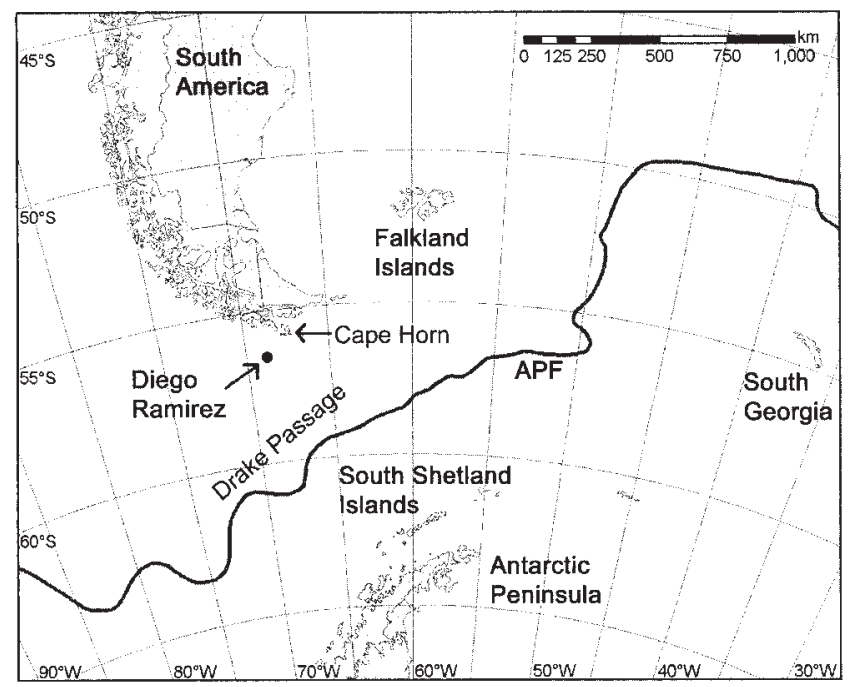

Fig. 1. Location of Diego Ramírez Islands (56³1'S, $\left.68^{\circ} 44^{\prime} \mathrm{W}\right)$, showing their proximity to the South American continent, the Antarctic Peninsula and the approximate location of the Antarctic Polar Front (APF). 


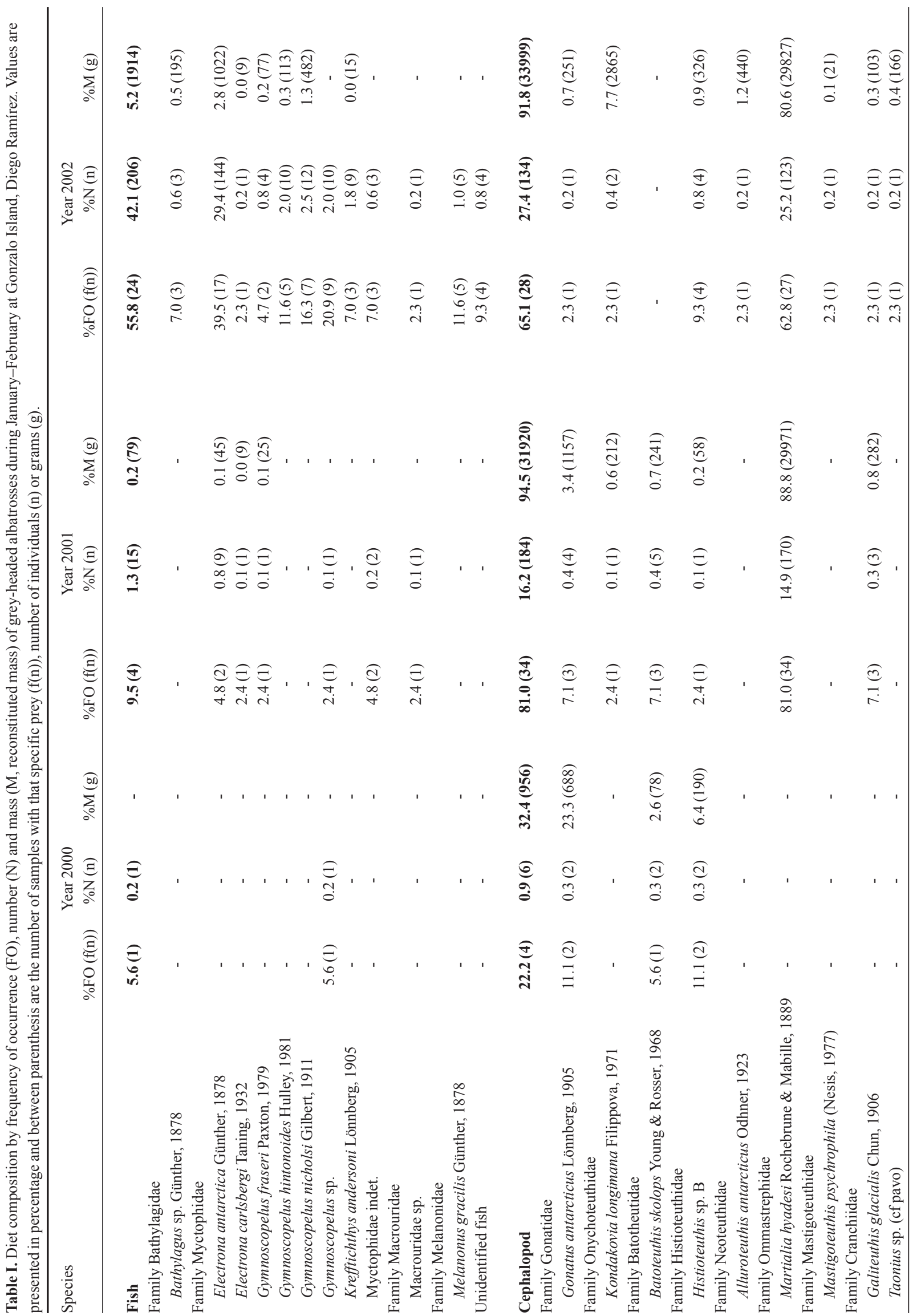




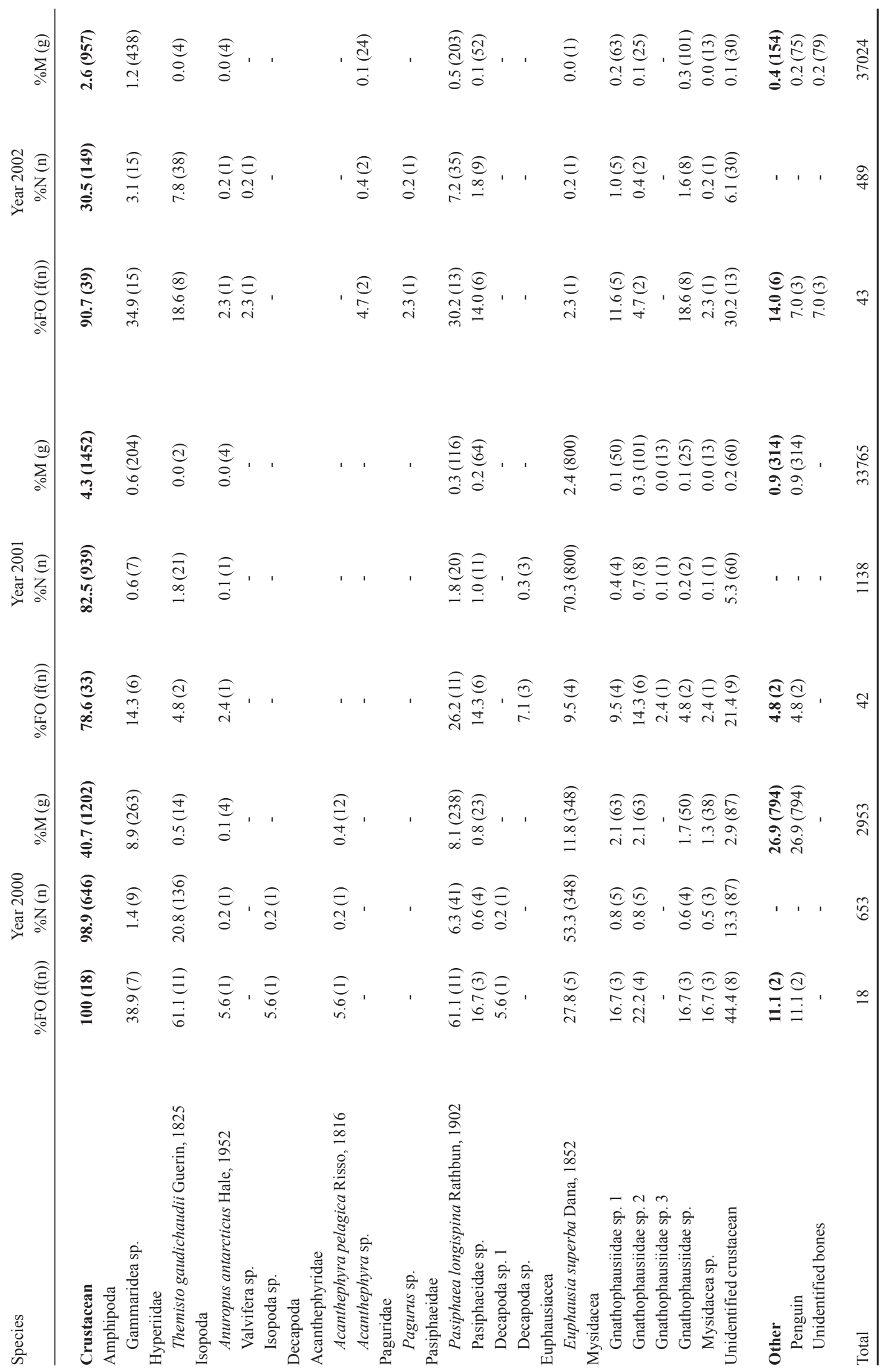


et al. 2002, Xavier et al. 2003a), as well neritic fish over the continental shelf off South America (see Cherel et al. 1999). However, the diet of Diego Ramírez grey-headed albatrosses had not been assessed prior to this study. The sympatric black-browed albatross ( $T$. melanophrys [Temminck, 1839]) population from Diego Ramírez have a high degree of dependence on local fisheries as a food source (Arata \& Xavier 2003), which in turn impacts negatively on the adult survival (Arata \& Moreno 2002). As the Chilean Patagonian toothfish fishery operates in the continental slope surrounding the Diego Ramírez Islands (Moreno et al. 2003), some degree of interaction of greyheaded albatrosses with this fishery can also be expected, as it was described for the South Georgia population (Ashford et al. 1995).

Here we provide the first description of the diet of the grey-headed albatross chicks at the Diego Ramírez Islands. We use this information to estimate feeding habitat preferences during breeding, niche partitioning with the sympatric black-browed albatross population at Diego Ramírez, and to explain interannual differences on chick growth rate. Finally, we discuss some preliminary hypotheses on the factors affecting the availability of main prey of grey-headed albatrosses, and consequently their breeding performance, during chick-rearing.

\section{Materials and methods}

\section{Study site and logistics}

The Diego Ramírez archipelago comprises three main islands: Norte Island and surrounding islets (24 ha), Bartolomé Island (93 ha, $190 \mathrm{~m}$ height) and Gonzalo Island (38 ha, $140 \mathrm{~m}$ height) (Schlatter \& Riveros 1997). The islands are inhabited by black-browed and grey-headed albatrosses breeding in mud flat and tussock grass habitats. The Chilean navy operates a lighthouse and look-out station at Gonzalo Island, which they resupply three times a year. Navy visits to the island provided the opportunity to conduct the current research but limited the time available to November-February of each year.

\section{Diet analysis}

A total of 103 food samples from grey-headed albatross chicks were collected at Gonzalo Island during January and February of $2000(n=18), 2001(n=42)$ and $2002(n=43)$. These were taken in two sampling events, one at the beginning of the post-brooding stage, end of January, and the other 2-3 weeks later, during February. Samples were obtained from chicks immediately after they had been fed by a parent, by inverting the chick over a plastic bag and gently squeezing its stomach and massaging its throat. This procedure induced the chick to vomit into the bag. Chicks were made to vomit only once during the season. Stomach emptiness of each sampled chick was verified by palpation
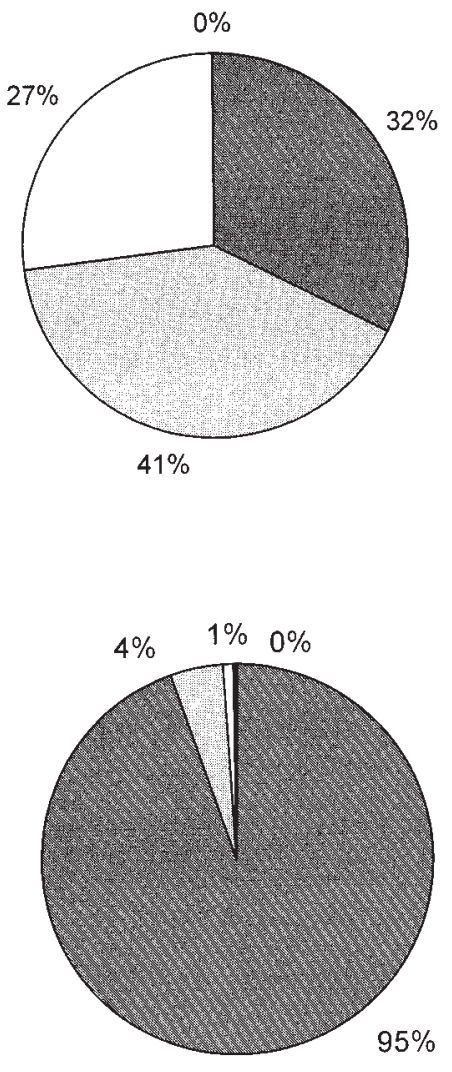

2001

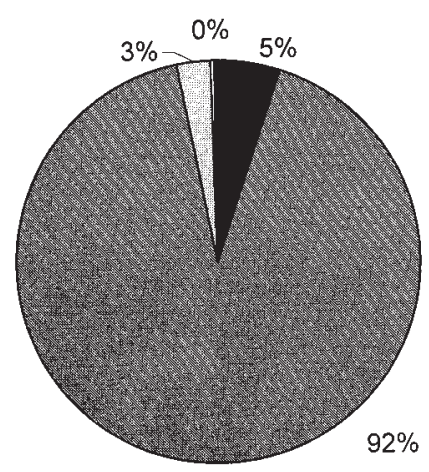

2002

Fig. 2. Contribution of each prey item to the total diet by reconstituted mass (fish $=$ black, cephalopod $=$ dark grey, crustacean $=$ light grey, carrion $=$ white $)$.

of its abdominal wall.

Samples were weighed whole (total mass), drained through a $1 \mathrm{~mm}$ mesh sieve and weighed again (solid mass) using an electronic balance $( \pm 1 \mathrm{~g})$. Solid fractions were then preserved in $95 \%$ ethanol in individual bags and sent to the laboratory.

Fish prey were identified and quantified from the otoliths found in the samples using the keys of Hecht (1987), Williams \& McEldowney (1990), Smale et al. (1995) and Reid (1996). Otolith length and width was measured to 
$\pm 0.01 \mathrm{~mm}$ using a reticule ocular in a binocular microscope, if not disabled by erosion. Fish length and mass were estimated from the otolith dimensions using the formulas in Williams \& McEldowney (1990) and Reid (1996), after being corrected for erosion as described by Reid \& Arnould (1996). Length and mass equations for Gymnoscopelus hintonoides were estimated from raw data presented in Williams \& McEldowney (1990) and they are: $\mathrm{SL}=19.152 \mathrm{e}^{0.655 O W}\left(r^{2}=0.76\right)$, Mass $=0.0533 \mathrm{e}^{2.179 O W}\left(r^{2}=\right.$ $0.84), n=6$, fish range $=33-137 \mathrm{~mm}$, where SL equals standard fish length $(\mathrm{mm})$ and $\mathrm{OW}$ equals otolith width (mm).

The number of fish present in each sample was estimated from the number of otoliths pairs (left/right) of similar sizes and unpaired otoliths. Total mass composition of each fish species was estimated from the otolith numbers and the mean reconstituted individual prey masses estimated from measurable otoliths.

The cephalopod beaks were identified according to Clarke (1986), Rodhouse et al. (1992) and a beak reference collection held at the British Antarctic Survey, UK. The lower rostral length (LRL) of the cephalopod beaks was measured to $\pm 0.01 \mathrm{~mm}$ with vernier callipers. Allometric equations predicting mantle length and mass from LRL were taken from Clarke (1986) and Rodhouse et al. (1990) and used to estimated total mass composition for each cephalopod species.

Crustaceans were identified using the keys of Retamal (1981), Kirkwood (1982, 1983), Barnard (1991), Murano (1999) and Vinogradov (1999). The number of individuals present was estimated using eye pairs or head numbers. The mass of crustacean species was determined using wet mass estimations from samples where crustaceans were only lightly digested and only one crustacean species was present; for a few species it was not possible to estimate individual mass (see Table I). To account for mass loss due to digestion, a further correction factor was applied at the end of the study: arbitrary factors of 1.2 and 1.5 were applied depending upon whether digestion was considered to be light or medium, respectively. For Themisto gaudichaudii an arbitrary wet mass of $0.1 \mathrm{~g}$ per individual was used.

Diet composition was assessed using frequency of occurrence, numerical abundance and percentage by mass (reconstituted mass from hard part remains) following Duffy \& Jackson (1986) to enable comparison with other dietary studies and to allow for biases peculiar to each method of analysis. The number and mass frequency of each prey type was estimated in relation to the number and mass of all prey found during the same year. For cephalopods, mass contribution was estimated only from beaks considered to be fresh (i.e. with buccal muscles still attached to it). This distinction was drawn because of the long persistence of cephalopods beaks in seabird stomachs (Furness et al. 1984).

\section{Chick's growth rate}

Chick's growth rate was estimated each season to assess potential effects of interannual changes of diet mass and/or composition on breeding performance. Thirty chicks were weighed twice per week from hatching to end of February and their growth rate was estimated during their linear growth phase, i.e. between 15 and 60 days old (Tickell \& Pinder 1975). Interannual comparison of the linear models was made using dummy variables (Zar 1999, p. 436).

\section{Diet comparison with black-browed albatrosses at Diego Ramirez}

Diet overlap between grey-headed and black-browed albatrosses (Arata \& Xavier 2003) at Diego Ramírez was assessed using the dietary overlap index described by Croxall et al. (1997). Two indexes were estimated, the first using only mass contribution of each main prey item (fish, cephalopod, crustacean, other) and the second, using all prey items found in the diet of both albatrosses species.

\section{Results}

\section{Diet composition}

We obtained 103 samples of chick regurgitates during early chick rearing (January-February) of the grey-headed albatross during 2000, 2001 and 2002. The mean mass of samples was similar between 2001 and 2002 but it was significantly lower during 2000 respect $2002(t=-2.044$,

Table II. Solid and liquid constituents of the diet of grey-headed albatrosses at Gonzalo Island, Diego Ramírez

\begin{tabular}{|c|c|c|c|c|c|c|}
\hline \multirow[t]{2}{*}{ Parameter } & \multicolumn{2}{|c|}{ Year 2000* } & \multicolumn{2}{|c|}{ Year 2001} & \multicolumn{2}{|c|}{ Year 2002} \\
\hline & Mean (1 SD) & Range & Mean (1 SD) & Range & Mean (1 SD) & Range \\
\hline Total mass by sample (g) & $1044(296)^{*}$ & $530-1600$ & $1121(358)$ & $333-1960$ & $1248(468)$ & $607-2152$ \\
\hline Solid mass (g) & $432(200)^{*}$ & $175-670$ & $432(207)$ & $62-998$ & $364(225)$ & $49-1044$ \\
\hline$\%$ solid & $38.4(14.0)^{*}$ & $22.6-56.0$ & $37.9(12.7)$ & $12.1-74.8$ & $28.1(11.3)$ & $6.1-55.3$ \\
\hline$\%$ liquid & $61.6(14.0)^{*}$ & $44.0-77.4$ & $62.1(12.7)$ & $25.2-87.9$ & $71.9(11.3)$ & $44.7-93.9$ \\
\hline $\mathrm{N}$ & $6^{*}$ & & 42 & & 43 & \\
\hline
\end{tabular}

*only includes samples taken in February by problems in the filtering process during January 2000

**estimated from difference between total and solid mass 
$P=0.046$ ) (Table II). The liquid component of the samples was only partially filtered during January 2000 due to saturation of the sieve used, caused by solidification of the oil fraction of the sample; this problem was subsequently rectified. However, the solid mass could not be estimated for those samples. To compare sample solid mass between years, we used only the mean solid mass for February each year. These were $432 \mathrm{~g}, 503 \mathrm{~g}$ and $502 \mathrm{~g}$ in 2000, 2001 and 2002 respectively, differences were not significant $\left(F_{(2,44)}=\right.$ $0.299, P=0.743$ ).

During 2000 crustaceans were the main prey taken (41\% by reconstituted mass) while cephalopods were of secondary importance, contributing $32 \%$ to the total mass.
On the contrary, cephalopods dominated the diet in 2001 and 2002 , with $95 \%$ and $92 \%$ of total estimated mass, respectively (Fig. 2).

Fresh cephalopods were represented by nine taxa belonging to eight squid families. Cephalopods were present in $22 \%, 81 \%$ and $65 \%$ of all samples in 2000,2001 and 2002, respectively, and accounted for $32 \%, 95 \%$ and $92 \%$ of the total reconstituted mass in the same years (Table I). In 2000, when the squid contribution was low, the main species taken was Gonatus antarcticus, with $23 \%$ by mass, followed by Histioteuthis sp. B ( $6 \%$ by mass). During 2001 and 2002, Martialia hyadesi was the predominant species, accounting for $89 \%$ and $81 \%$ of the total mass and
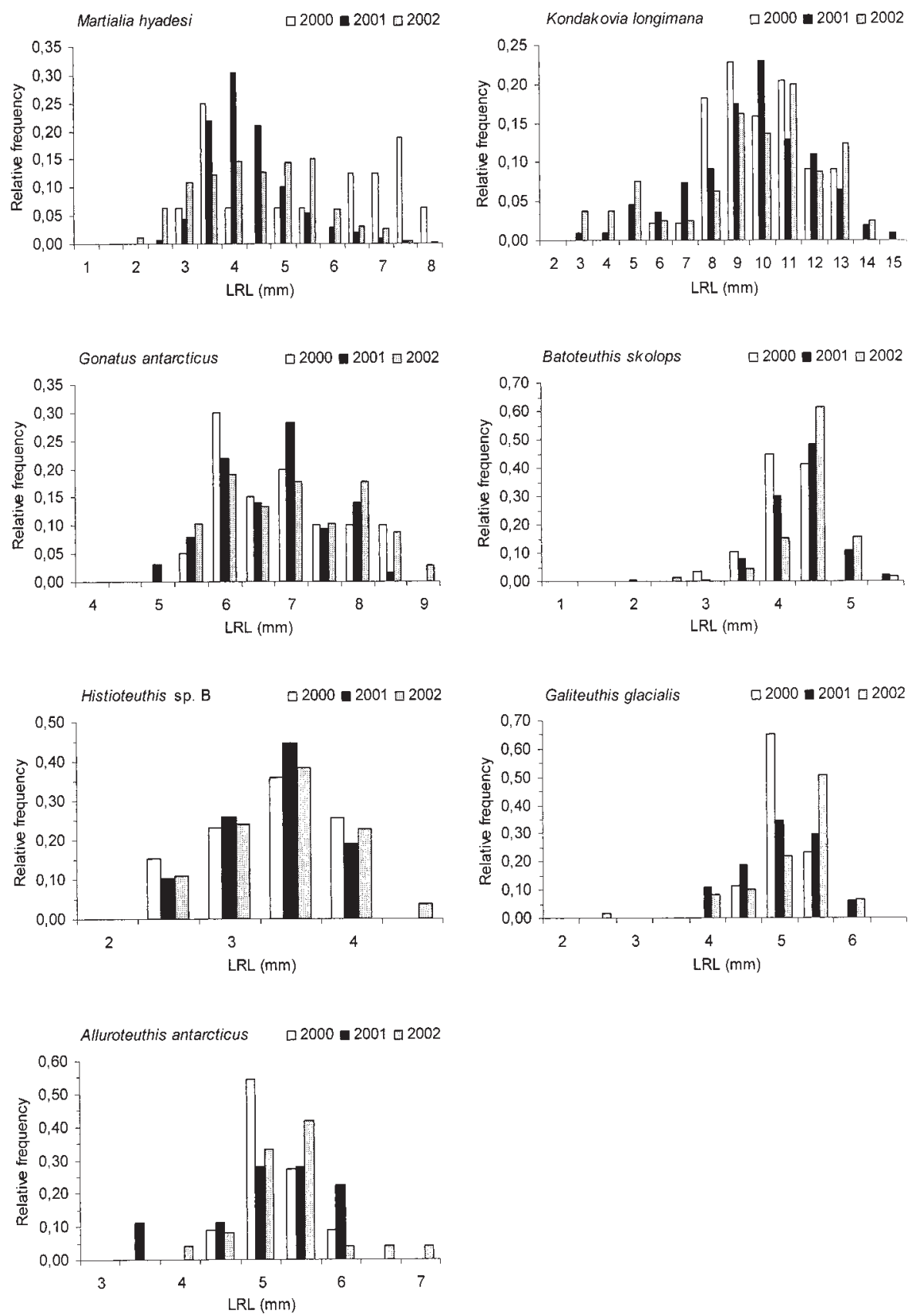

Fig. 3. Lower Rostral Length (LRL) accumulative frequency of cephalopod beaks found in greyheaded albatross stomachs. 
being present in $81 \%$ and $63 \%$ of the samples of both years, respectively. Kondakovia longimana was the only other species of importance by mass (8\%) in 2002.

Considering all the beaks found in the samples, cephalopods were represented by 18 squid taxa and one Octopodidae (Appendix I). Martialia hyadesi was the dominant species by number $(75 \%$ and $42 \%)$ and reconstituted mass (74\% and 40\%) during 2001 and 2002. By contrast, this species represented only $8.0 \%$ by number and $9.7 \%$ by mass during 2000 . Other species important by number were $G$. antarcticus, Batoteuthis skolops, Histioteuthis sp. B and Galiteuthis glacialis (in 2000); $K$. longimana was significant by mass in all years. Length frequency distribution of the beaks' lower rostral length (LRL), of the more abundant species in the diet, shows a similar frequency distribution between years (Fig. 3). Only $M$. hyadesi presented a different pattern, with a bimodal distribution in the beak LRL frequency during 2000 that corresponds to mantle length sizes of $193 \pm 11 \mathrm{~mm}$ and $297 \pm$ $13 \mathrm{~mm}$. During 2001 and 2002, the mantle length frequency of this species was unimodal, with means of $212 \pm 24 \mathrm{~mm}$ and $217 \pm 35 \mathrm{~mm}$, respectively.

Thirteen crustacean taxa were found in the diet of greyheaded albatrosses during the three years sampled. They were present in $100 \%, 79 \%$ and $91 \%$ of all samples, and accounted for $99 \%, 83 \%$ and $31 \%$ of the total number of individuals recorded, during years 2000, 2001 and 2002, respectively (Table I). Crustaceans were the main prey item during 2000 with $41 \%$ of the total mass estimated. During 2001 and 2002, they contributed less than $5 \%$ to the total reconstituted mass despite their high contribution by number, given their low individual weight. The most important crustacean was Euphausia superba, which represented $11.8 \%, 2.4 \%$ and $0.0 \%$ of the total mass during 2000, 2001 and 2002, respectively. In 2000, Gammarideans (8.9\%), Pasiphaeidae (8.9\%) and Gnathophausiidae species (5.9\%) were the only other crustacean important by mass (Table I).

Fish were represented by nine taxa, six of them being myctophids. Fish prey accounted by less than $6 \%$ by mass in all years. During 2002, when fish had the higher representation, myctophids were present in $56 \%$ of samples, accounted for $42 \%$ of individual prey and $5 \%$ by mass of the reconstituted diet (Table I). The species more represented were Electrona antarctica and Gymnoscopelus sp. (including G. nicholsi). The size of the myctophids consumed were in the following ranges: E. antarctica, 61-99 mm; G. nicholsi, 140-157 mm; G. hintonoides, 79-90 and 97-110 $\mathrm{mm}$; Krefftichthys andersoni, $47-58 \mathrm{~mm}$.

Other items found in the samples were penguin remains and unidentified bones (Table I, 'others'). During 2000, penguin remains represented $27 \%$ of the total reconstituted mass, mainly accounted by a penguin leg (eroded) found in one sample. In 2001 only penguin feathers (314 g) were found, while a single piece of penguin skin ( $75 \mathrm{~g}$ ) was found in 2002. Unidentified bones and flesh were also recorded during 2002.

Another item found in the diet samples was plastic litter with two bottle tops in both 2000 and 2002.

Overall, mean reconstituted mass per sample during the two sampling times each year was lower in 2000 , with $84 \mathrm{~g}$ and $191 \mathrm{~g} \mathrm{sample}^{-1}$ in January and February, respectively. In both 2001 and 2002, mean reconstituted masses per sample were $>500 \mathrm{~g}$ in January and $>1000 \mathrm{~g}$ in February (Fig. 4).

\section{Chick's growth rate}

Chick's growth rates estimated were lower in 2000 and
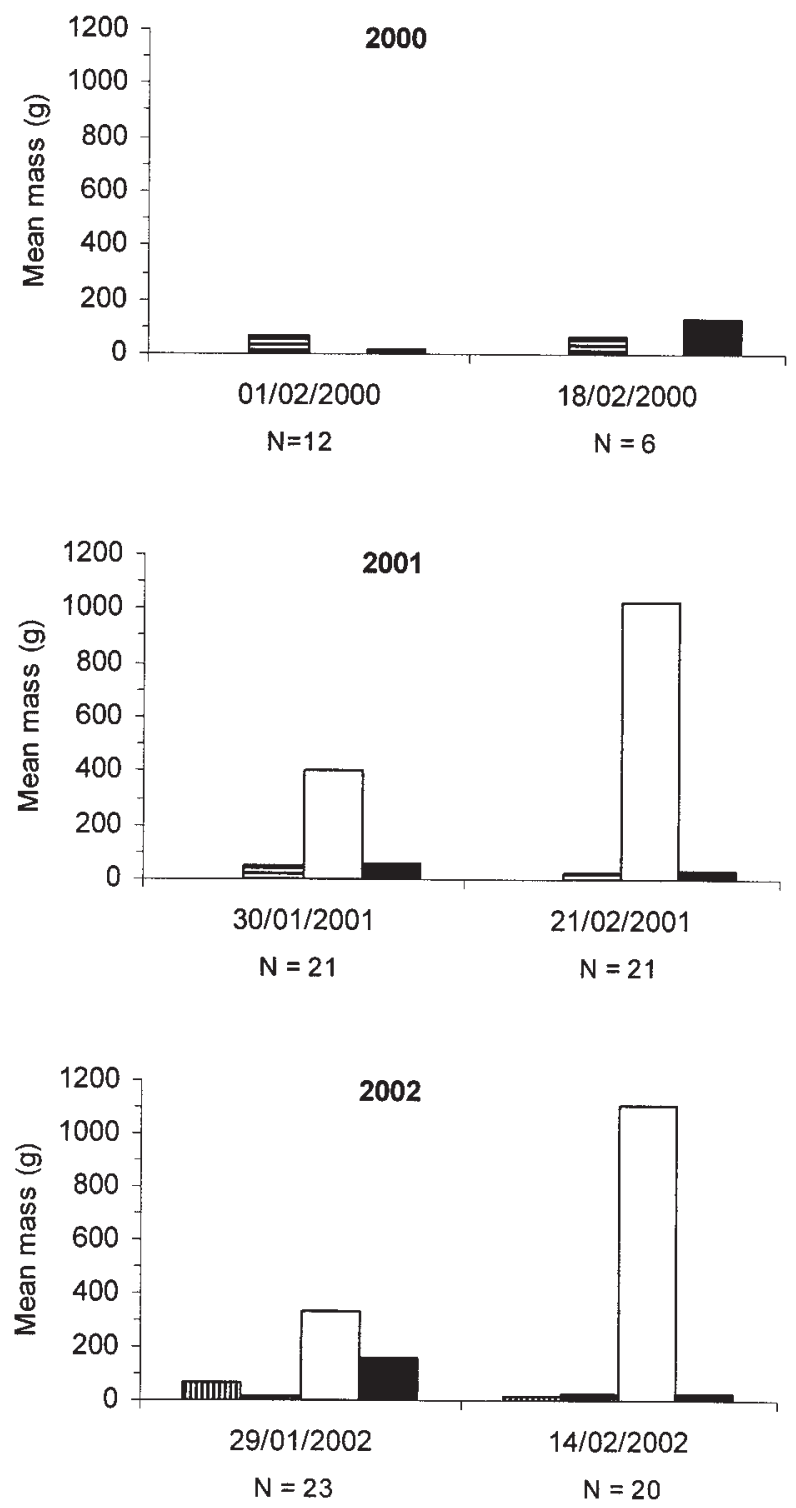

四 fish 自crustacean $\square$ Martialia hyadesi $\square$ other cephalopods

Fig. 4. Reconstituted mean mass per sample of the main prey items in the grey-headed albatross diet for each sampling date. 
Table III. Adjusted model for the linear growth phase (15-60 days old) of grey-headed albatross chicks during 2000, 2001 and 2002 seasons at Gonzalo Island, Diego Ramírez.

\begin{tabular}{lcccccc}
\hline Season & $\begin{array}{c}\text { Growth rate } \\
\left(\mathrm{g} \cdot \mathrm{d}^{-1}\right) \\
\text { mean } \pm \mathrm{SD}\end{array}$ & $P$ & $\begin{array}{c}\text { Intercept } \\
(\mathrm{g})\end{array}$ & $P$ & \multicolumn{3}{c}{$\begin{array}{c}\text { Chicks } \\
\text { sampled* }\end{array}$} & $r^{2}$ \\
\hline 2000 & $45.2 \pm 2.9$ & 0.0000 & $292.3 \pm 103.8$ & 0.0059 & 25 & 0.7284 \\
2001 & $65.9 \pm 2.2$ & 0.0000 & $-233.6 \pm 79.4$ & 0.0035 & 27 & 0.7344 \\
2002 & $77.4 \pm 2.0$ & 0.0000 & $-490.4 \pm 80.5$ & 0.0000 & 21 & 0.8409 \\
\hline
\end{tabular}

*chicks alive at the moment of the last sampling event each season

higher in 2002 (Table III). Interannual differences were all significant, as it is revealed by the dummy variable estimates of the slopes (AGE*YEAR: 2000 vs $2001=$ $0.0207, P=0.000 ; 2000$ vs $2002=0.0322, P=0.000 ; 2001$ vs $2002=0.0115, P=0.000$ ).

\section{Diet comparison with black-browed albatrosses at Diego Ramirez}

The dietary overlap index with black-browed albatrosses at Gonzalo Island between main prey items (fish, cephalopod, crustacean, other) was $0.079,0.310$, and 0.204 during breeding seasons 2000, 2001 and 2002, respectively. Between all prey species it was 0.004, 0.286, and 0.107, during the same seasons.

\section{Discussion}

\section{Diet composition}

Squid were the main prey of grey-headed albatrosses at the Diego Ramírez Islands during early chick rearing in 2001 and 2002, with crustacean or fish as secondary prey items. However in 2000, crustacean, squid and carrion contributed similarly by reconstituted mass to the diet, whereas fish otoliths were not found. Despite the former, fish remains were found in 13 of the 18 samples taken in 2000. Mean solid mass per sample was lower in 2000 (February), although differences were not statistically significant, whereas mean reconstituted mass per sample was significantly lower in that year. It is possible, therefore, that fish were under-represented in the diet sampling analysis in 2000.

In terms of specific prey, the diet of grey-headed albatrosses was dominated by the squid Martialia hyadesi, a species known to live along the Antarctic Polar Front (Rodhouse et al. 1996). Secondary species, including myctophids (E. antarctica and G. nicholsi) and other cephalopods (mainly G. antarcticus and K. longimana), are also found at the Antarctic Polar Front (Williams \& McEldowney 1990, Xavier et al. 1999). During 2000, when a shortage of $M$. hyadesi occurred, main prey found in samples were carrion, the squid $G$. antarcticus, krill and other crustaceans, most of them also known to inhabit
Antarctic/sub-Antarctic waters. The presence of one species of the family Macrouridae, a deep-water fish family that is a common bycatch in the Patagonian toothfish fishery (Arata, personal observation), in one sample both in 2001 and 2002 is the single evidence that suggests some interaction with fishing activities. These results indicate that grey-headed albatrosses feeding young chicks at Diego Ramírez Islands exploit mostly Antarctic/sub-Antarctic waters during January-February, with minimal association with commercial fishing operations over the continental shelf of southern Chile.

\section{Dependence on Martialia hyadesi}

Martialia hyadesi plays a key role during the breeding period of grey-headed albatrosses at Diego Ramírez. The absence of this prey species in 2000 caused the mean reconstituted mass per sample to be significantly lower during this season (Fig. 4). This lower food amount given to the chicks would in turn explain the significant low chick growth rate estimated during 2000. Similar results were recorded for the grey-headed albatross population at South Georgia (Xavier et al. 2003a), where a shortage of M. hyadesi was also found in 2000 , causing breeding success to decline. This is the first record in literature that the breeding output of two different albatross populations has been affected by the availability of a single prey species simultaneously. Giving that dietary differences between these populations suggest different foraging areas (see below), this finding implies a large scale process affecting the availability of $M$. hyadesi in the south-west Atlantic Ocean and Drake Passage regions.

There is interest in the development of a commercial fishery for this squid in the South-west Atlantic Ocean (González \& Rodhouse 1998). This fishery may have serious implications for the conservation of grey-headed albatrosses, considering that about $70 \%$ of the world breeding pairs are nesting on South Georgia and Diego Ramírez Islands (Gales 1998). Therefore, it should be a priority task to understand the factors affecting the interannual variability in $M$. hyadesi abundance, and applying this knowledge to the management of any future fishery.

\section{Martialia hyadesi availability to albatrosses}

The processes affecting the distribution and abundance of M. hyadesi are poorly understood. Considering the life history traits of squids, with high fecundity, high mortality during early life stages and lower mortality as adults, abundance of $M$. hyadesi could be determined mainly by processes affecting eggs and newly hatched individuals, as has been described for the squid Illex argentinus (Waluda et al. 1999).

Size of the squids found in the stomach samples indicates that grey-headed albatrosses consume juveniles hatched 
during the previous spawning season (autumn-winter, González et al. 1997). As M. hyadesi is semelparous, probably spawning at two years old (González \& Rodhouse 1998), abundance of $M$. hyadesi juveniles could depend on the direct effect of environmental variables during the previous spawning event or past environmental anomalies that affected the spawning stock, two years previously. Note, however, that the absent of $M$. hyadesi from greyheaded albatross diet samples does not mean the total failure of the $M$. hyadesi cohort. As flying predators, albatrosses can only dive to a few metres beneath the surface and thus, when squid abundance is under a given threshold, albatrosses could not be able to detect them.

We tested the effect of environmental anomalies on the $M$. hyadesi recruitment using information of $M$. hyadesi presence in grey-headed albatross diet samples taken at South Georgia and compared it with the occurrence of ENSO events and sea surface temperature anomalies, such as the Antarctic Circumpolar Wave (ACW) (see Appendix II). Both environmental factors have been previously associated with M. hyadesi abundance (Xavier et al. 2003a, González et al. 1997). The contingency analysis showed no correlation between $M$. hyadesi availability to albatrosses and the ACW anomaly (ACW at South Georgia: $P=0.476$; ACW at Drake Passage: $P=0.238$ ). By contrast, ENSO events are weakly correlated with the occurrence of $M$. hyadesi in the grey-headed albatross diet at South Georgia $(P=0.091)$. However, this was mostly due to $M$. hyadesi being available in years that did not follow ENSO events $(n=8)$. Two of the four cases when the availability of $M$. hyadesi to albatrosses was low, matched with the occurrence of ENSO events. The other two cases of low presence of $M$. hyadesi in grey-headed albatross diet samples happened two years after the last ENSO event and could be explained by a reduced spawning stock hatched under ENSO conditions. This circumstantial evidence suggests that ENSO events could affect the recruitment of $M$. hyadesi and, subsequently, the breeding performance of grey-headed albatrosses.

\section{Comparison with other diet studies}

The importance of $M$. hyadesi in the diet of Diego Ramírez grey-headed albatrosses is similar to that at other breeding islands: South Georgia $\left(56^{\circ} 30^{\prime} \mathrm{S}, 38^{\circ} 40^{\prime} \mathrm{W}\right.$; Xavier et al. 2003a), Marion (Nel et al. 2000) and Campbell Island (Waugh 1998), perhaps reflecting the exploitation of the same habitat (Antarctic Polar Front) throughout their breeding range. Although at the other breeding islands $M$. hyadesi is also important in grey-headed albatross diet, it represents less than $55 \%$ by mass, in comparison with the $81-89 \%$ by mass found in this study in 2001 and 2002 . This difference could be explained by an interaction of the following causes: a greater relative abundance of M. hyadesi in Drake's Passage in comparison to other regions, low competition for this prey in this area, and/or a greater abundance of alternative prey in other regions. $M$. hyadesi is abundant in the epipelagic ecosystem of the Antarctic Polar Front in the South-west Atlantic Ocean (Rodhouse \& White 1995) and thus, it is likely to have great abundance in the Drake's Passage as well. Moreover, strong competition for $M$. hyadesi within the foraging range of grey-headed albatrosses nesting at Diego Ramírez during the breeding season, when most predators are central place foragers, seems unlikely. At South Georgia, where $M$. hyadesi is important in the diet as well but represents a lower fraction of it (Xavier et al. 2003a), the grey-headed albatross breeding size is five times larger than at Diego Ramirez (Gales 1998), leading to a higher intra-specific competition for this prey. Diet at South Georgia seems to be compensated with Antarctic krill, which is abundant in close proximity to the islands. This prey is further away from Diego Ramirez Islands and thus, its presence in our diet samples was low. Then, although the distribution and abundance of potential albatross' prey in the Drake Passage are poorly known, it seems that the great abundance of $M$. hyadesi and relative low abundance of alternative prey, combined with a relative lower inter and intra-specific competition for it, may explain the highest presence of $M$. hyadesi in the diet of grey-headed albatrosses found in this study.

Fish and crustacean prey had a low representation in our diet samples. Myctophid fish and Antarctic krill, main secondary prey at Diego Ramirez, are distributed in Antarctic waters, roughly over $500 \mathrm{~km}$ away. These species are common prey at Marion, South Georgia and Kerguelen islands, which are located in or south of the Antarctic Polar Frontal Zone (Nel et al. 2000, Cherel et al. 2002, Xavier et al. 2003a). Antarctic krill is also a common prey at South Georgia (Xavier et al. 2003a). The Diego Ramírez Islands are located north of the Antarctic Polar Front, which could explain the low contribution of these Antarctic prey. Similar result was found at Campbell Island, located in the subAntarctic Zone, where the fish southern blue whiting (Micromesistius australis) taken over the Campbell shelf is a frequent prey (Waugh et al. 1999). Thus, distance from breeding islands to the Antarctic Polar Front seems to determines the main dietary differences between populations. The biogeographical area where Diego Ramírez is located determine a different prey availability compared to other breeding sites and could reinforce the importance of $M$. hyadesi. The importance of other fish species living over the South American continental shelf could diminish as a consequence of strong competition with the sympatric black-browed albatross (see below).

Grey-headed albatrosses at South Georgia, the closest breeding population of this species to Diego Ramírez, also prey mostly on $M$. hyadesi during chick rearing in 'normal' years (Xavier et al. 2003a). Niche theory predicts mechanisms reducing intra-specific competition, with 
spatial segregation of feeding areas between populations being the main mechanism for niche partitioning proposed for albatrosses (Cherel et al. 2002). The evidence suggests that this mechanism also operates in this case. Secondary prey items of South Georgia and Diego Ramírez greyheaded albatross populations differed. South Georgia albatrosses consume significant amounts of Antarctic krill and the lamprey Geotria australis (Croxall et al. 1997, Xavier et al. 2003a), whereas at Diego Ramírez Antarctic krill was poorly represented and G. australis was totally absent from the samples. These results support the hypothesis for niche segregation and suggest that albatrosses at both localities do not overlap in their foraging areas during the chick rearing season. During 2000, when $M$. hyadesi was almost absent in diet samples at both localities, grey-headed albatrosses at South Georgia fed mainly on Antarctic krill (61\% by mass), with other prey species representing less than $10 \%$ (Xavier et al. 2003a). At Diego Ramírez, penguin remains ( $27 \%$ by mass), the squid Gonatus antarcticus (23\% by mass) and Antarctic krill ( $12 \%$ by mass) were the main prey taken by grey-headed albatrosses. That year grey-headed albatrosses at South Georgia foraged near the South Shetland Islands shelf (Xavier et al. 2003b, using satellite tracking), an area within the foraging range of albatrosses from Diego Ramírez. This suggests that in years of low $M$. hyadesi availability, the foraging distribution of both populations may overlap, leading to potential intraspecific competition between these two populations.

\section{Comparison with black-browed albatross diet at Diego Ramírez}

The diets of grey-headed and black-browed albatrosses nesting at Diego Ramírez were highly segregated. The diet of black-browed albatrosses was dominated by hoki (66-89\%), Macruronus magellanicus, a benthopelagic species that commonly occurs as bycatch in fisheries at Southern Chile (Arata \& Xavier 2003). As fisheries in Southern Chile are concentrated over the continental shelf, black-browed albatrosses during breeding seasons must feed mainly over shelf waters. In contrast, grey-headed albatrosses fed mostly on $M$. hyadesi, which is most prevalent in Antarctic/sub-Antarctic waters. This pattern is consistent with the at-sea distribution described for these two albatross species elsewhere (Prince et al. 1998, Waugh et al. 1999, Cherel et al. 2000), and gives further support to the hypothesis that spatial segregation is the main mechanism of niche partitioning between these two albatross species (Cherel et al. 2002).

The trophic niche segregation of these two albatross species at Diego Ramírez is the highest recorded. Diet overlap reported for other colonies (considering all prey taxa and using the same index) are 0.64 and $0.67-0.98$ at South Georgia (Croxall et al. 1997, Xavier et al. 2003a) and
0.84 at Kerguelen (estimated from Cherel et al. 2002). The difference with the values estimated in this study $(<0.29)$ is remarkable. This difference possibly reflects the location of the Diego Ramírez Islands near both the vast South American continental shelf and the Antarctic Polar Front, whereas other breeding islands are more oceanic, having a smaller continental shelf that leads to a higher overlapping in their foraging areas. The congregation of black-browed albatrosses along fishing boats seems to accentuate the foraging difference between both species found elsewhere. Information about at-sea distribution of both species nesting at Diego Ramírez is needed to confirm the presumed segregation in their foraging areas during the breeding season and, potential intraspecific competition with the closest population at South Georgia, particularly during years of poor availability of their main prey.

\section{Acknowledgements}

We wish to thank to Alejandro Sepúlveda and Marcos Muñoz, for their assistance in the field and the Chilean Navy personnel at Diego Ramírez lighthouse during November-February of 1999/2000, 2000/01 and 2001/02, for their friendly company during our voluntary retirement. Also thanks to Carlos Jara, Layla Osman, Paul Rodhouse and Dick Williams by their help in species identification. This research was made possible thanks a collaboration programme between the Instituto Antártico Chileno (INACH), the Universidad Austral de Chile (UACH), the Australian Antarctic Division (AAD) and the British Antarctic Survey (BAS). Further financial assistance for laboratory expenses were provided to JA through a project of the Dirección de Investigación y Desarrollo (DID), UACH. Financial support for JA at Gonzalo Island was provided by a scholarship from the Comisión Nacional de Investigación Científica y Tecnológica (CONICYT), Chile. Comments by Barbara Wienecke improved an early draft. We thank Roger Kirkwood for his constructive review of the paper.

\section{References}

Arata, J. \& Moreno, C.A. 2002. Progress Report of Chilean Research on Albatross Ecology and Conservation. Document WG-FSA 02/18. Hobart, TAS: CCAMLR, 15 pp.

Arata, J. \& XaVier, C.J. 2003. The diet of black-browed albatrosses at Diego Ramírez Islands, Chile. Polar Biology, 26, 638-647.

Ashford, J.R., Croxall, J.P., Rubilar, P.S. \& Moreno, C.A. 1995. Seabird interactions with longlining operations for Dissostichus eleginoides around South Georgia, April to May 1994. CCAMLR Science, 2, 111-121.

BARNARD, J.L. 1991. The families and genera of marine gammaridean Amphipoda (except Marine Gammaroids), Part 1. Records of the Australian Museum, Supplement 13, 1-866.

Cherel, Y., Waugh, S. \& Hanchet, S. 1999. Albatross predation of juvenile southern blue whiting (Micromesistius australis) on the Campbell Plateau. New Zealand Journal of Marine and Freshwater Research, 33, 437-441. 
Cherel, Y., Weimerskirch, H. \& Trouvé, C. 2000. Food and feeding ecology of the neritic-slope forager black-browed albatross and its relationships with commercial fisheries in Kerguelen waters. Marine Ecology Progress Series, 207, 183-199.

Cherel, Y., Weimerskirch, H. \& Trouvé, C. 2002. Dietary evidence for spatial foraging segregation in sympatric albatrosses (Diomedea spp.) rearing chicks at Îles Nuageuses, Kerguelen. Marine Biology, 141, $1117-1129$

Clarke, M.R. 1986. A handbook for the identification of cephalopod beaks. Oxford: Claredon Press, $273 \mathrm{pp}$.

Croxall, J.P., Prince, P.A. \& ReID, K. 1997. Dietary segregation of krilleating South Georgia seabirds. Journal of Zoology, London, 242, $531-556$.

DuFFY, D.C. \& JACKSON, S. 1986. Diet studies of seabirds: a review of methods. Colonial Waterbird, 9, 1-17.

Furness, B.L., Laugksch, R.C. \& Duffy, D.C. 1984. Cephalopod beaks and studies of seabirds diets. Auk, 101, 619-620.

GaLES, R. 1998. Albatross populations: status and threats. In RoBERTSON, G. \& Gales, R., eds. Albatross biology and conservation. Chipping Norton: Surrey Beatty \& Sons, 20-45.

GonZÁlez, A.F. \& Rodhouse, P.G. 1998. Fishery biology of the seven star flying squid Martialia hyadesi at South Georgia during winter. Polar Biology, 19, 231-236.

González, A.F., Tratan, P.N., Yau, C. \& Rodhouse, P.G. 1997. Interactions between oceanography, ecology and fishery biology of the ommastrephid squid Martialia hyadesi in the South Atlantic. Marine Ecology Progress Series, 152, 205-215.

Hecht, T. 1987. A guide to the otoliths of Southern ocean fishes. South African Journal of Antarctic Research, 17, 2-87.

KirKWOOD, J.M. 1982. A guide to the Euphausiacea of the Southern Ocean. ANARE Research Notes, 1, 1-45.

KiRKWOOD, J.M. 1983. A guide to the Decapoda of the Southern Ocean. ANARE Research Notes, 11, 1-47.

Moreno, C.A., Hucke-Gaete, R. \& Arata, J. 2003. Interacción de la pesquería de bacalao de profundidad con mamíferos y aves marinas. Project FIP 2001-31, Final Report <www.fip.cl>

Murano, M. 1999. Mysidacea. In Boltovskoy, D., ed. South Atlantic zooplankton. Leiden: Backhuys Publishers, 1099-1140.

Nel, D.C., Lutjeharms, J.R.E., Pakhomov, E.A., Ansorge, I.J., Ryan, P.G. \& Klages, N.T.W. 2001. Exploitation of mesoscale oceanographic features by grey-headed albatross Thalassarche chrysostoma in the southern Indian Ocean. Marine Ecology Progress Series, 217, 15-26.

Nel, D.C., Nel, J.L., Ryan, P.G., Klages, N., Wilson, R.P. \& Robertson, G. 2000. Foraging ecology of grey-headed mollymawks at Marion Island, southern Indian Ocean, in relation to longline fishing activity. Biological Conservation, 96, 219-231.

Prince, P.A., Croxall, J.P., Trathan, P.N. \& Wood, A.G. 1998. The pelagic distribution of South Georgia albatrosses and their relationships with fisheries. In Robertson, G. \& Gales, R., eds. Albatross biology and conservation. Chipping Norton: Surrey Beatty \& Sons, 137-167.

REID, K. 1996. A guide to the use of otoliths in the study of predators at South Georgia. Cambridge: British Antarctic Survey, 39 pp.
ReID, K. \& ARnould, J.P.Y. 1996. The diet of Antarctic fur seals Arctocephalus gazella during the breeding season at South Georgia. Polar Biology, 16, 105-114.

Retamal, M.A. 1981. Catálogo ilustrado de los crustáceos decápodos de Chile. Gayana Zoológica, 44, 7-110.

Rodhouse, P.G., Arnbom, T., Fedak, M.A., Yeatman, J. \& Murray, A.W.A. 1992. Cephalopod prey of the southern elephant seal, Mirounga leonina L. Canadian Journal of Zoology, 70, 1007-1015.

Rodhouse, P.G., Prince, P.A., Clarke, M.R. \& Murray, A.W.A. 1990. Cephalopod prey of the grey headed albatross Diomedea chrysostoma. Marine Biology, 104, 353-362.

Rodhouse, P.G., Prince, P.A., Trathan, P.N., Hatfield, E.M.C., Watkins, J.L., Bone, D.G., MurPhy, E.J. \& White, M.G. 1996. Cephalopods and mesoscale oceanography at the Antarctic Polar Front: satellite tracked predators locate pelagic trophic interactions. Marine Ecology Progress Series, 136, 37-50.

Rodhouse, P.G. \& White, M.G. 1995. Cephalopods occupy the ecological niche of epipelagic fish in the Antarctic Polar Frontal Zone. Biological Bulletin, 189, 77-80.

Schlatter, R.P. \& Riveros, G. 1997. Historia natural del Archipiélago Diego Ramírez, Chile. Serie Cientifica INACH, 47, 87-112.

Smale, M.J., Watson, G. \& Hecht, T. 1995. Otolith atlas of the southern African marine fishes. Ichthyological Monographs of the JLB Smith Institute of Ichthyology, No. 1, xiv.

Tickell, W.L.N. \& PINDER, R. 1975. Breeding biology of the blackbrowed albatross Diomedea melanophrys and grey-headed albatross D. chrysostoma at Bird Island, South Georgia. Ibis, 117, 433-451.

Vinogradov, G. 1999. Amphipoda. In Boltovskoy, D., ed. South Atlantic zooplankton. Leiden: Backhuys Publishers, 1141-1240.

Waluda, C.M., Trathan, P.N. \& Rodhouse, P.G. 1999. Influence of oceanographic variability on recruitment in the Illex argentinus (Cephalopoda: Ommastrephidae) fishery in the South Atlantic. Marine Ecology Progress Series, 183, 159-167.

WAUGH, S.M. 1998. Ecologie compare et dynamique de populations de deux espèces d'albatros. $\mathrm{PhD}$ thesis, Universite de Rennes 1, France, $171 \mathrm{pp}$. [Unpublished].

Waugh, S.M., Weimerskirch, H., Cherel, Y., Shankar, U., Prince, P.A. \& SAGAR, P.M. 1999. Exploitation of the marine environment by two sympatric albatrosses in the Pacific Southern Ocean. Marine Ecology Progress Series, 177, 243-254.

Williams, R. \& McEldowney, A. 1990. A guide to the fish otoliths from waters off the Australian Antarctic Territory, Heard and Macquarie Islands. ANARE Research Notes, 75, 1-173.

Xavier, J.C., Croxall, J.P. \& Reid, K. 2003a. Inter-annual variation in the diets of two albatross species breeding at South Georgia: implications for breeding performance. Ibis, 145, 593-610.

Xavier, J.C., Croxall, J.P., Trathan, P.N. \& Wood, A.G. 2003b. Feeding strategies and diets of breeding grey-headed and wandering albatrosses at South Georgia. Marine Biology, 143, 221-232.

Xavier, J.C., Rodhouse, P.G., Trathan, P.N. \& Wood, A.G. 1999. A geographical information system (GIS) atlas of cephalopod distribution in the Southern Ocean. Antarctic Science, 11, 61-62.

ZAR, J.H. 1999. Biostatistical analysis, 4th ed. Upper Saddle River, NJ: Prentice-Hall, 663 pp. 


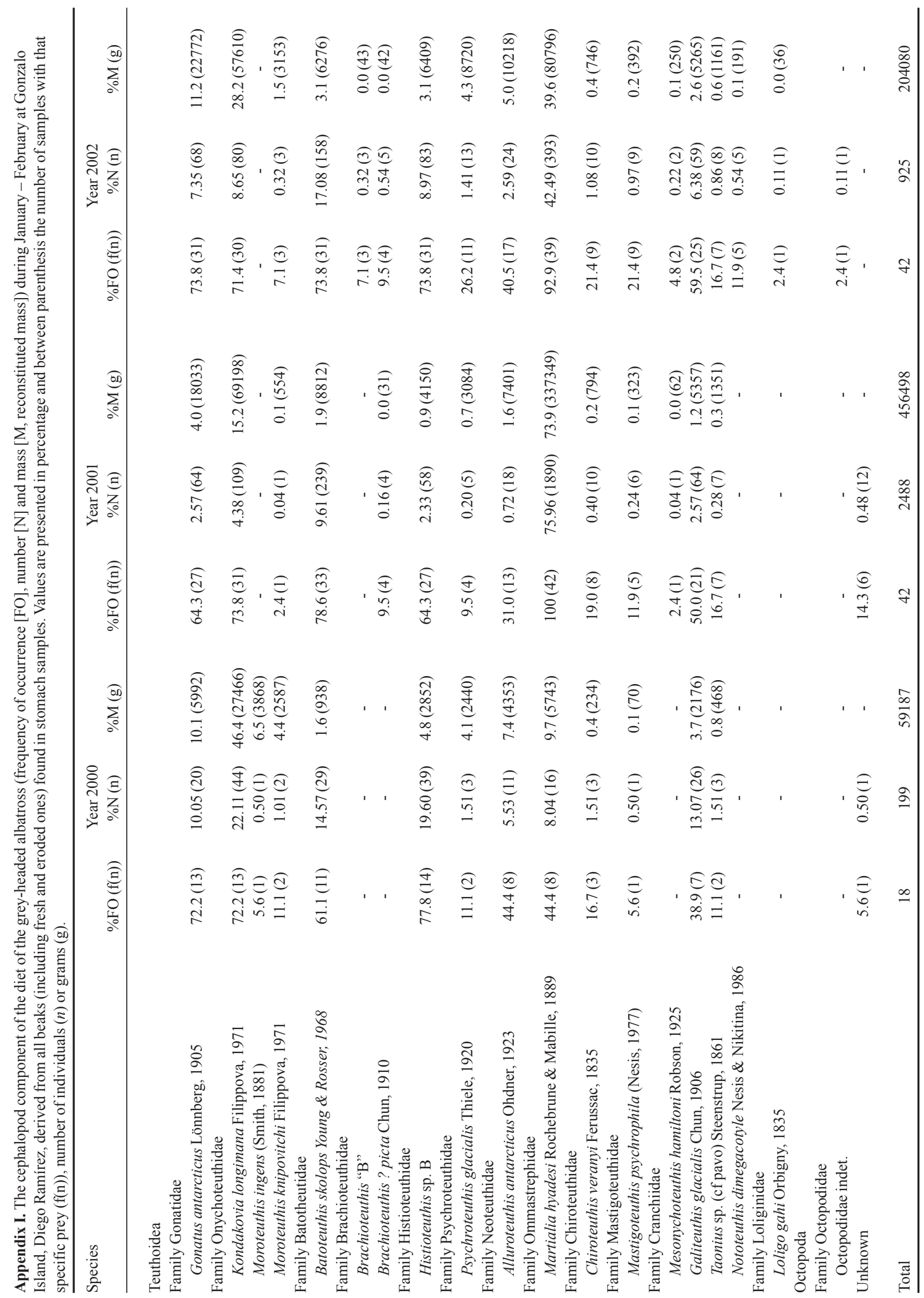


Appendix II. Martialia hyadesi availability to albatrosses (as found in grey-headed albatross diet samples) was examined in relation to the occurrence of ENSO events and sea-surface temperature anomalies in the Antarctic Circumpolar Wave (ACW) in the Drake Passage (D.P.) and South Georgia (S.G.) areas. ENSO events and ACW anomalies during the second semester of each year, when squid recruits, were correlated with squid availability during the following summer (when samples were taken) because these events could affect the early stages of development of M. hyadesi. M. hyadesi presence in grey-headed albatross diet is from Prince (1980), Clarke \& Prince (1981), Rodhouse et al. (1990), Reid et al. (1996), Xavier et al. (2003a) and this study.

ENSO occurrence and ACW anomalies were obtained from the internet: $<\mathrm{http}: / /$ acw.ucsd.edu/ACW/index_evolution.html $>$ and

$<$ http://ingrid.ldeo.columbia.edu/SOURCES/.Indices/ensomonitor.html $>$. M. hyadesi availability and ENSO or ACW anomalies were correlated through contingency tables and the significance of correlations were assessed statistically using the Fisher's exact test. Data used in the analyses are presented below.

\begin{tabular}{|c|c|c|c|c|}
\hline \multirow[t]{2}{*}{ Year } & \multirow{2}{*}{$\begin{array}{l}\text { M. hyadesi } \\
\text { availability }\end{array}$} & \multirow{2}{*}{$\begin{array}{c}\text { ENSO } \\
\text { 2nd semester on }\end{array}$} & \multicolumn{2}{|c|}{$\mathrm{ACW}$ on 2 nd semester at } \\
\hline & & & S.G. & D.P. \\
\hline 1975 & & No & & \\
\hline 1976 & $\mathrm{High} \leftarrow$ & No & & \\
\hline 1977 & High & Yes & & \\
\hline 1981 & & No & & \\
\hline 1982 & & Yes & warm & cold \\
\hline 1983 & & Yes & cold & normal \\
\hline 1984 & Low & No & normal & warm \\
\hline 1985 & & No & warm & warm \\
\hline 1986 & High & Yes & warm & cold \\
\hline 1991 & & Yes & cold & cold \\
\hline 1992 & & No & cold & cold \\
\hline 1993 & & No & warm & warm \\
\hline 1994 & Low & No & normal & normal \\
\hline 1995 & & No & normal & cold \\
\hline 1996 & High & No & warm & cold \\
\hline 1997 & High & Yes & cold & warm \\
\hline 1998 & Low & No & cold & warm \\
\hline 1999 & High & No & warm & warm \\
\hline 2000 & Low & No & warm & normal \\
\hline 2001 & High & No & normal & cold \\
\hline 2002 & High & yes & & \\
\hline
\end{tabular}

